\title{
Design and Simulation of Parallel Manipulator for Vehicle Driving Simulator
}

\author{
Khalid Ali Abdelaziz Ali ${ }^{1}$, Liu Ying ${ }^{2}$ \\ ${ }^{1}$ Tianjin University of Technology and Education, Dagu Nanlu Road, Tianjin, China \\ ${ }^{2}$ Professor, Tianjin University of Technology and Education, Dagu Nanlu Road, Tianjin, China
}

\begin{abstract}
A 3-Dof RPS parallel manipulator is selected in order to realize the motion of the driver simulator. For every limb, the structural designs are carried, which include the screw shaft and nut calculation, the load calculation, the motors selection, and so on. According to calculation, a model is established by using UG 6.0. modeling simulation in ADAMS software It supplied the basis for the further research.
\end{abstract}

Keywords: degree of freedom ; joints desgin; nut selection; motor specifications selection; desgin and modeling; simulatiom using ADAMS

\section{Introduction}

The design of parallel manipulators can be trace back to 1962 , when Gough and Whitehall (1962) devised a six-linear jack system for used as a universal tire- testing machine. Stewart (1965) designs a platform manipulator for use as an aircraft simulator in 1965. Since then a systematic study of the kinematic structure of parallel manipulators in 1983 was performed by Hunt (1983). Parallel manipulators have been studied extensively by numerous researchers (Clearly and Arai, 1991; Fitcher , 1986; Grffis and Duffy, 1989; Innocenti and Parenti-Castelli, 1990; Mohamed and Duffy, 1985; Nanua et al., 1990; Zhang and Song, 1994) [1]

Parallel platform is gaining popularity and widely used in many applications with the development and application of virtual reality technology which include among others, vehicle driving simulator, parallel kinematic machine, flight simulator, simulation of seismic waves, pointing and polishing machine and earthquake wave simulator etc. Moreover, it continue to expand into new application areas[2] .Parallel manipulator is a field of interest for a many researchers due its diversified applications, high accuracy and speed more than serial manipulator.

Researchers are battling to come up with new ideas on how to deal with the working space problem of the manipulator without compromising the other design parameters. Its accuracy and repeatability is an attribute to its high stiffness and low inertia and also it has great ability to withstand heavy load due to the fact that the load is merely assumed to be distributed to the platform which in turn the platform is supported by limbs., the parallel robots consists of fixed base which might be of various shapes depend on designers choice and applications intended to performed, but usually the base shape is not playing an important role during the application. Attached to the base are limbs which is an assembly of more than one joint, the joint assembly also depend on the designers choice. Attached to the limbs of the parallel robot is the moving platform which served as end effectors[1]
Because parallel manipulator has characteristics as above, it is able to be used as vehicle driving simulator. When it is used as vehicle driving manipulator, there are many advantages such as low cost, professional driver training, high precision, safety, and so on.

\section{Degree of Freedom of Parallel Manipulator}

For the vehicle driving simulator which the given parameters are listed in Table 1, a spatial 3-DOF, RPS parallel manipulator (shown in Figure 1) is selected. As shown, three identical limbs connect the moving platform by spherical joints and fixed base by revolute joints. And each limb consists of an upper member and lower member connected by a prismatic joint. Ball screws can be used to vary the lengths of the prismatic joints and therefore to control the location of the moving platform [3]

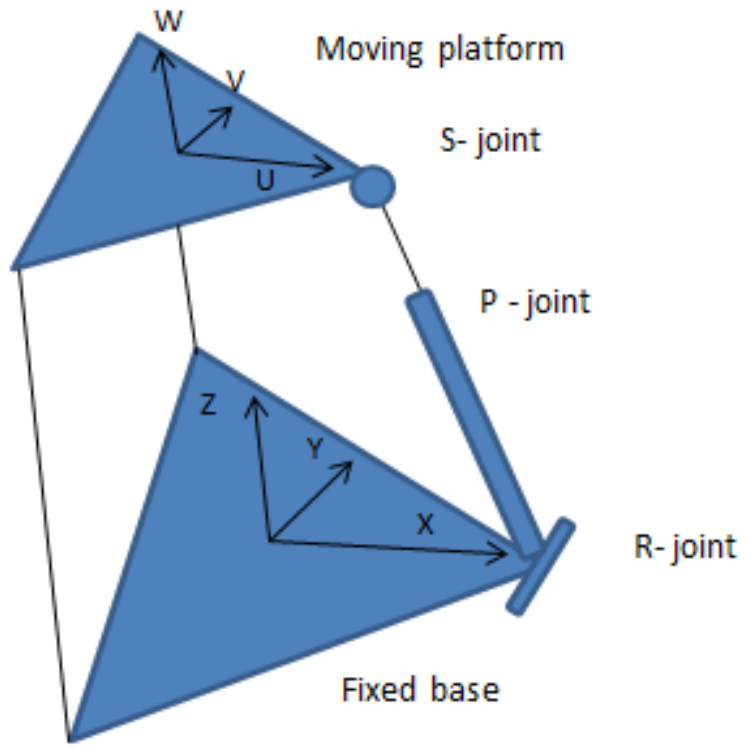

Figure 1: spatial 3-dof 3RPS parallel manipulator

$$
F=\lambda(n-j-1)+\sum_{i} f_{i}-f_{p}
$$

Where, $\mathrm{F}$ is degrees of freedom of a mechanism. fi is degrees of relative motion permitted by joint $\mathrm{i} . \mathrm{j}$ is number of joints in a 


\section{International Journal of Science and Research (IJSR) \\ ISSN (Online): 2319-7064 \\ Index Copernicus Value (2013): 6.14 | Impact Factor (2014): 5.611}

mechanism. $\mathrm{n}$ is number of links in a mechanism. $\lambda$ is degrees of freedom of the space in which a mechanism is intended to function. $\mathrm{fp}$ is number of passive degrees of freedom in a mechanism .

So from figure (3) using formal (1)

$$
F=\lambda(n-j-1)+\sum f_{i}-f_{p}=3 D O F
$$

So, it is a symmetrical manipulator, which the number of degree of freedom is equal to the number of limbs which is equal to the total number of loops of that manipulator.

Table 1: The given parameters

\begin{tabular}{|l|l|}
\hline quantity & symbol \\
\hline Mass & $\mathrm{m}$ \\
\hline Stroke length & $\mathrm{ls}$ \\
\hline Maximum Velocity & $\mathrm{Vmax}$ \\
\hline Time for Speed up & $\mathrm{t} 1$ \\
\hline Time for Speed down & $\mathrm{t} 3$ \\
\hline Frequency & $\mathrm{n}$ \\
\hline Work Life hours & $\mathrm{h}$ \\
\hline AC Servo Motor & $\mathrm{N}$ \\
\hline Transmission Ratio & $\mathrm{i}$ \\
\hline Friction factor on Guide Face & $\mu$ \\
\hline Resistance Force on Guide Face & $\mathrm{f}$ \\
\hline Inertia Torque of Motor & $\mathrm{Jm}$ \\
\hline
\end{tabular}

\section{Structural Design of Prismatic Joint}

A screw shaft is chosen to realize the motion of prismatic joint. Its design majors in the following ways.

\subsection{Lead and Shaft Diameter design}

As shown in Figure 3, lead means advance of the nut along the length of the screw per revolution, Screw shaft diameter meanings largest diameter over the threaded section (at top of threads), root diameter meanings smallest diameter over the threaded section (at base of threads).
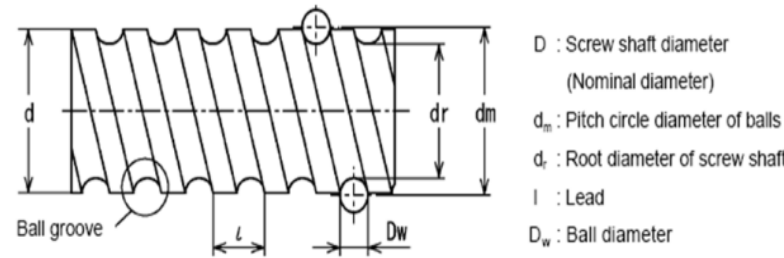

Figure 2: Screw shaft

Using equation (2) to calculate the lead:

rotational speed $($ rev per $\mathrm{min})=$ Linear velocity $(\mathrm{mm}$ per $\mathrm{min}) /$ Lead (mm per rev)

So lead is $=\mathrm{Vmax} / \mathrm{N}=18 \mathrm{~mm}$

From the table (2) below, 20mm lead is chosen which correspond to the $36 \mathrm{~mm}$ diameter of the screw shaft.
Table 2 : Lead and diameter selection

\begin{tabular}{|c|c|c|c|c|c|c|c|c|c|c|c|}
\hline \multirow{2}{*}{$\begin{array}{c}\text { Screw shat } \\
\text { outer dameter }\end{array}$} & \multicolumn{10}{|c|}{ Lead } \\
\hline & 1 & 2 & 4 & 5 & 6 & 8 & 10 & 12 & 16 & 20 & 24 \\
\hline 20 & & & & $\bullet$ & & & $\bullet$ & & & $\bullet$ & \\
\hline 25 & & & & $\bullet$ & & & $\bullet$ & & & & \\
\hline 28 & & & & & $\bullet$ & & & & & & \\
\hline 30 & & & & & & & & & & & \\
\hline 32 & & & & & & & $\bullet$ & & & & \\
\hline 36 & & & & & & & $\bullet$ & & & $\bullet$ & $\bullet$ \\
\hline 40 & & & & & & & $\bullet$ & & & & \\
\hline 45 & & & & & & & & $\bullet$ & & & \\
\hline 50 & & & & & & & & & $\bullet$ & & \\
\hline
\end{tabular}

\section{: Standard stock}

Standard stock stock

So, the maximum speed is obtained from the lead $(20 \mathrm{~mm})$, it is $1800 \mathrm{rpm}$.

\subsection{Pitch and Angle of Thread}

1. The Pitch

$$
\mathrm{Ph}=\mathrm{ns} \times \mathrm{p}
$$

Where, $\mathrm{p}$ is the screw pitch (distance between identical points of two consecutive threads) and ns is the number of starts.

So, $\mathrm{p}=\mathrm{ph} / \mathrm{ns}=10 \mathrm{~mm}$.

\section{Angle of Thread}

The angle formed by the two sides of the thread (or their projections) with each other.

$$
\Psi=60^{\circ}
$$

\subsection{Calculating Length Between Bearing Supports (Shaft Length)}

Using Figure (5) and equation (4) for calculation shaft length L:

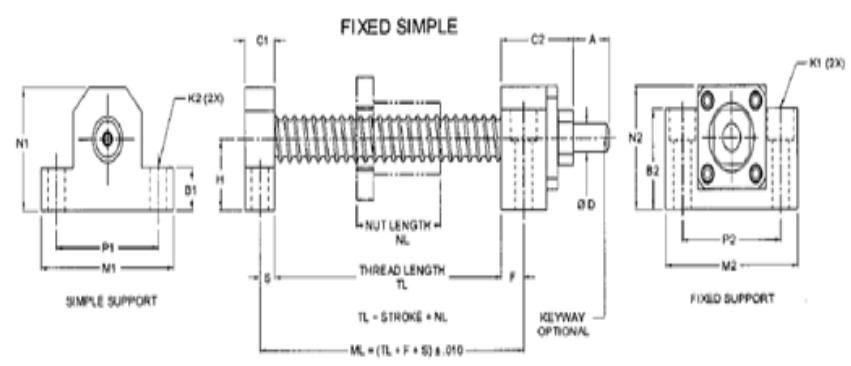

Figure 3: Ball screw method of support

$\mathrm{L}=$ Stroke length + ball nut length $+_{\mathrm{S}}+\mathrm{F}+$ Desired over travel $=648 \mathrm{~mm}$

\subsection{Support Method}

The supporting method is determined from equation (4) of the screw shaft critical speed.

$$
C_{S}=\frac{\mathrm{F}\left(1.2 \times 10^{8}\right) \mathrm{dr}}{\mathbb{L}^{2}}
$$

Where: CS is critical speed (rpm). F is end support factor. dr is 


\section{International Journal of Science and Research (IJSR) \\ ISSN (Online): 2319-7064 \\ Index Copernicus Value (2013): 6.14 | Impact Factor (2014): 5.611}

root diameter of screw $(\mathrm{mm})$, the value is $31.2 \mathrm{~mm}$ from table(3). $\mathrm{L}$ is length between supports $(\mathrm{mm})$.

So, $\mathrm{F}=2$.

The fixed -simple conform to the maximum speed shown the figure (6) is selected.

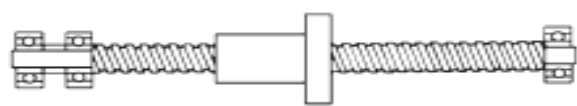

Figure 4: Fixed simple

\subsection{Maximum Axial Load}

The resultant axial load $\mathrm{Fa}$ is given by equation (6 -12):

Acceleration

$$
\alpha=\frac{v_{\max }}{t_{1}}=6 \mathrm{~ms}^{-2}
$$

Below are the axial load calculated when the limb is in:

Accelerating:

$$
\mathrm{F}_{\mathrm{a} 1}=\mathrm{m} \cdot \mathrm{g}+\mathrm{m} . \alpha+\mathrm{f}=8456.667 \mathrm{~N}
$$

Constant acceleration increase:

$\mathrm{F}_{\mathrm{a} 2}=\mathrm{m} \cdot \mathrm{g}+\mathrm{f}=5256.667 \mathrm{~N}$

Slow increase:

$$
\mathrm{F}_{\mathrm{a} 3}=\mathrm{m} \cdot \mathrm{g}-\mathrm{m} . \alpha+\mathrm{f}=2056.667 \mathrm{~N}
$$

Deceleration:

$$
\mathrm{F}_{\mathrm{a} 4}=\mathrm{m} \cdot \mathrm{g}-\mathrm{m} \cdot \alpha-\mathrm{f}=1996.667 \mathrm{~N}
$$

Constant deceleration decrease:

$$
\mathrm{F}_{\mathrm{a} 5}=\mathrm{m} \cdot \mathrm{g}-\mathrm{f}=5196.667 \mathrm{~N}
$$

Slow decrease:

$$
\mathrm{F}_{\mathrm{a} 6}=\mathrm{mg}+\mathrm{m} . \alpha-\mathrm{f}=8396.667 \mathrm{~N}
$$

Therefore, the maximum axial load acting on the screw shaft occurs when the limb accelerates up. The value is Fmax= Fa1.

\subsection{Rate Of Risk Allowed By The Screw Speed}

With reference to table 3-3,

he coefficients associated with installation of the ball screw shaft is 15.1 , as it conform to the supporting method.

Table 3: Coefficients Associated With Installation

\begin{tabular}{|c|c|c|c|}
\hline S/No. & Fixing Method & $\lambda_{1}$ & $\lambda_{2}$ \\
\hline 1 & Fixed-Free & 1.875 & 3.4 \\
\hline 2 & Simple-Simple & 3.142 & 9.7 \\
\hline 3 & Fixed-Simple & 3.927 & 15.1 \\
\hline 4 & Fixed - Fixed & 4.73 & 21.9 \\
\hline
\end{tabular}

Given Data:

Installation spacing $(\mathrm{lb})=(648-130) \mathrm{mm}=518 \mathrm{~mm}$

Lead screw Axis root diameter, $\mathrm{dr}=31.2 \mathrm{~mm}$

Calculassions:

$N=\lambda_{2} \times \frac{\mathrm{d}_{\mathrm{r}}}{\mathrm{l}_{\mathrm{b}}^{\mathrm{z}}} \times 10^{7}=17557.878 \mathrm{~min}-1$

\section{Nut Selection}

The diameter of the screw axis and lead is known, so nut can be selected using $\mathrm{Ca}$ (dynamic load rating $(\mathrm{N})$ ) and Cao (static load rating $(\mathrm{N})$ ).

\begin{tabular}{|c|c|c|c|c|c|c|c|}
\hline \multirow{2}{*}{ 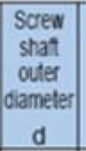 } & \multirow{2}{*}{$\begin{array}{c}\text { Lead } \\
\mathrm{Ph}\end{array}$} & \multirow[b]{2}{*}{ Model No. } & \multirow{2}{*}{$\begin{array}{c}\text { Ball } \\
\text { center- } \\
\text { to-center } \\
\text { dm }\end{array}$} & \multirow{2}{*}{$\begin{array}{c}\text { Thread } \\
\text { minor } \\
\text { diameter } \\
\text { dc }\end{array}$} & \multirow{2}{*}{$\begin{array}{l}\text { No. of } \\
\text { loaded } \\
\text { circuits } \\
\text { Rous } x \text { uns }\end{array}$} & \multicolumn{2}{|c|}{ Basic load rating } \\
\hline & & & & & & $\begin{array}{l}\mathrm{Ca} \\
\mathrm{kN}\end{array}$ & $\begin{array}{l}\mathrm{C} \approx \mathrm{a} \\
\mathrm{kN}\end{array}$ \\
\hline \multirow{13}{*}{36} & \multirow{5}{*}{10} & OBNF $3610-2.5$ & 37.75 & 30.5 & $1 \times 2.5$ & 27.6 & 63.3 \\
\hline & & BNF $3610-5$ & 37.75 & 30.5 & $2 \times 2.5$ & 50.1 & 126.4 \\
\hline & & OBNF $3610-7.5$ & 37.75 & 30.5 & $3 \times 2.5$ & 71.1 & 190.1 \\
\hline & & DK $3610-3$ & 37.75 & 30.5 & $3 \times 1$ & 28.8 & 63.8 \\
\hline & & DK $3610-4$ & 37.75 & 30.5 & $4 \times 1$ & 36.8 & 85 \\
\hline & \multirow{2}{*}{12} & OBNF $3612-2.5$ & 38 & 30.1 & $1 \times 2.5$ & 32.1 & 71.4 \\
\hline & & OBNF $3612-5$ & 38 & 30.1 & $2 \times 2.5$ & 58.4 & 142.1 \\
\hline & 16 & OBNF $3616-2.5$ & 38 & 30.1 & $1 \times 2.5$ & 32.1 & 71.4 \\
\hline & \multirow{2}{*}{20} & OBNF $3620-1.5$ & 37.75 & 30.5 & $1 \times 1.5$ & 17.6 & 38.3 \\
\hline & & BLK $3620-5.6$ & 37.75 & 31.2 & $2 \times 2.8$ & 54.9 & 134.3 \\
\hline & 24 & BLK $3624-5.6$ & 38 & 30.7 & $2 \times 2.8$ & 63.8 & 151.9 \\
\hline & \multirow{2}{*}{36} & BLK $3636-2.8$ & 37.4 & 31.7 & $1 \times 2.8$ & 22.4 & 54.1 \\
\hline & & BLK $3636-3.6$ & 37.4 & 31.7 & $2 \times 1.8$ & 30.8 & 78 \\
\hline
\end{tabular}

BLK 3620-5.6 is selected as the nut type. The dynamic load is the load at will achieve the service life of $1 \times 10^{6} \mathrm{rev}$ $\left(\mathrm{C}_{\mathrm{a}}=54.9 \mathrm{KN}\right)$ and static load rating $\left(\mathrm{C}_{\mathrm{ao}}=134.3 \mathrm{KN}\right)$ from Table 3.

Table 3: No Preload Type of Precision Ball Screw

So BLK 3620-5.6 is selected as the nut type.

Selecting an end-cap type figure 5 , this models achieve stable motion in a high-speed rotation.

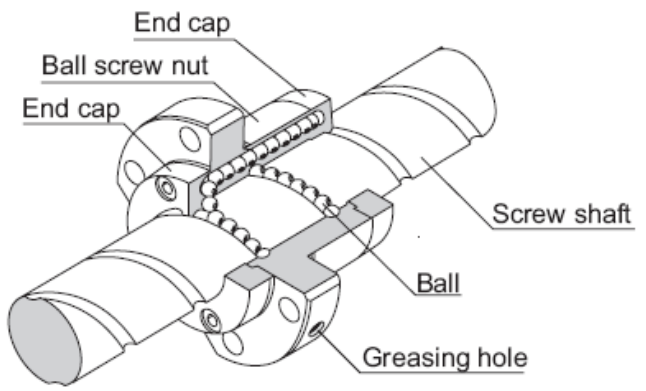

Figure 5: End-cap type

$F a_{\max }=$ Maximum static load (allowable axial load)

Table 4: Static safety factors

\begin{tabular}{|c|c|c|}
\hline machineries & Loading conditions & $F_{s}$ lower limit \\
\hline \multirow{2}{*}{$\begin{array}{c}\text { General industria } \\
1 \text { machineries }\end{array}$} & $\begin{array}{c}\text { When there } \\
\text { is no vibration or shock }\end{array}$ & $1 \sim 1.3$ \\
\cline { 2 - 3 } Machine tools & $\begin{array}{c}\text { When there } \\
\text { is vibration or shock }\end{array}$ & $2 \sim 3$ \\
\cline { 2 - 3 } & $\begin{array}{c}\text { When there } \\
\text { is no vibration or shock }\end{array}$ & $1 \sim 1.5$ \\
\hline $\begin{array}{c}\text { When there } \\
\text { is vibration or shock }\end{array}$ & $2.5 \sim 7$ \\
\hline
\end{tabular}

$$
\mathrm{Fa}_{\max }=\frac{c_{\mathrm{oa}}}{f_{s}}=67.15 \mathrm{KN}
$$

By comparison, we know that allowable axial load is greater than the maximum axial load $8456.667 \mathrm{~N}$, thus this model can meet the requirements.

\section{Working Life}

It depend on average number of revolutions per minute and rated life which in turns rated life depend on average axial load and maximum axial load and also the average axial load depend on maximum axial load and running distance.

Running distance when in acceleration and deceleration

$$
1_{1,4}=\frac{V_{\max } \times t_{1} \times 10^{s}}{2}=30 \mathrm{~mm}
$$

\section{Volume 4 Issue 12, December 2015}




\section{International Journal of Science and Research (IJSR) \\ ISSN (Online): 2319-7064}

Index Copernicus Value (2013): 6.14 | Impact Factor (2014): 5.611

Running distance with constant velocity increase and constant velocity decrease

$$
1_{2,5}=1_{\mathrm{s}}-\frac{\mathrm{W}_{\max } \times \mathrm{t}_{1}+\mathrm{Y}_{\max } \times \mathrm{t}_{3} \times 10^{3}}{2}=340 \mathrm{~mm}
$$

Running distance when in slowly acceleration increase and deceleration decrease

$$
1_{3,6}=\frac{V_{\max } \times t_{3} \times 10^{3}}{2}=30 \mathrm{~mm}
$$

To sum up, the average axial load is got:

$$
\begin{gathered}
F_{m}=\sqrt[3]{\frac{1}{2 \times l_{s}}\left(F_{a 1}^{3} \times l_{1}+F_{a 2}^{3} \times l_{2}+F_{a 3}^{3} \times l_{3}+F_{a 4}^{3} \times l_{4}+F_{a 5}^{3} \times l_{5}+F_{a 6}^{3} \times l_{6}\right)} \\
=2753 \mathrm{~N} \\
\mathrm{~F}_{\mathrm{m}}=5505.51 \mathrm{~N}
\end{gathered}
$$

\subsection{Rated Life}

Since dynamic load ratings $C_{a}$ (see Table 3 ) and load factor $f_{w}$ (see Table 5) are known, according to the average axial load $\mathrm{F}_{\mathrm{m}}$, the rated life $\mathrm{L}$ can be obtained:

$$
L=\left(\frac{C_{a}}{f_{w} \cdot F_{m}}\right)^{3} \times 10^{6}=2.35 \times 10^{9} \mathrm{rev}
$$

Similarly, according to the maximum axial load $F_{\max }$, the rated life L' can be obtained:

$$
L^{\prime}=\left(\frac{C_{a}}{f_{w} \cdot F_{\max }}\right)^{3} \times 10^{6}=6.33 \times 10^{8} \mathrm{rev}
$$

Table 5: Load Cooefficients

\begin{tabular}{|l|l|c|}
\hline $\begin{array}{l}\text { Vibration, } \\
\text { Impact }\end{array}$ & Velocity $(V)$ & $f_{W}$ \\
\hline Tiny & $V \leq 0.25 \mathrm{~m} / \mathrm{s}$ & $0.5 \sim 0.6$ \\
\hline Little & $0.25<V \leq 1 \mathrm{~m} / \mathrm{s}$ & $0.6 \sim 0.7$ \\
\hline Medium & $1<V \leq 2 \mathrm{~m} / \mathrm{s}$ & $0.7 \sim 1.0$ \\
\hline High & $V>2 \mathrm{~m} / \mathrm{s}$ & $1.0 \sim 1.5$ \\
\hline
\end{tabular}

\subsection{Average Number of Revolutions Per Minute}

Since number of times round per minute $\mathrm{n}=7 \mathrm{~min}^{-1}$, and stroke length ls and lead $\mathrm{Ph}$ are known, average number of Revolutions Per Minute can be calculated:

$$
\begin{aligned}
N_{m}=\frac{2 \times n \times l_{s}}{P h} & =240 \min ^{-1} \\
& =280 \mathrm{~min}^{-1}
\end{aligned}
$$

\subsection{Conversion from Revolution to Hours}

Since rated life $\mathrm{L}$ and the average number of revolutions per minute $\mathrm{Nm}$ are known, according to the average axial load, conversion from Revolution to Hours is

$$
L_{h}=\frac{L}{60 \cdot N_{m}}=163000 h
$$

$$
=172023.81 \mathrm{hrs}
$$

Similarly, according to the maximum axial load, working life is

$$
\begin{aligned}
L_{h}^{\prime}=\frac{L^{\prime}}{60 \cdot N_{m}}=43960 h \\
=440.476 \mathrm{hrs}
\end{aligned}
$$

\section{Motor Torque}

The frictional torques induced by external loads are:
Constant acceleration:

$\mathrm{T}_{1}=\frac{\mathrm{F}_{22 \mathrm{x} \mathrm{ph}}}{2 \times \pi \times \pi}=18591.419 \mathrm{Nmm} \quad$ with $90 \%$ efficiency

Constant deceleration:

$$
\mathrm{T}_{2}=\frac{\mathrm{F}_{25 \mathrm{x} \mathrm{ph}}}{2 \times \pi \times \eta}=18379.213 \mathrm{Nmm} \quad \text { with } 90 \% \text { efficiency }
$$

For acceleration operation

$$
\begin{gathered}
\mathrm{T}_{3}=\left(\mathrm{J}+\mathrm{J}_{\mathrm{m}}\right) \times \omega_{\mathrm{b}} \\
\mathrm{J}=\mathrm{m}\left(\frac{p h}{2 \pi}\right)^{2} \times i^{2} \times 10^{-6}+J_{S} \times i^{2}+J_{G}+J_{1} \times i^{2}
\end{gathered}
$$

Where: $\mathrm{m}$ is Load mass. $\mathrm{Ph}$ is Lead. $\mathrm{J}_{1}$ is Inertia moment of the screw. I is moderating ratio. $\mathrm{J}_{\mathrm{S}}$ is Inertia moment of the gear or else on screw. $J_{G}$ is Inertia moment of the gear or else on motor.

And,

$$
\begin{aligned}
& \mathrm{J}_{\mathrm{S}}(\text { screw })=\mathrm{D}^{4} \mathrm{x} \text { length } \mathrm{x} .028 \\
& \mathrm{D}=\text { diameter of pulley. } \\
& \mathrm{J}_{\mathrm{S}}=5.7 \mathrm{Kgmm}^{2}
\end{aligned}
$$

Therefore, $\mathrm{J}=5.7162 \mathrm{kgmm}^{2}$.

And,

$$
\omega_{\mathrm{b}}=\frac{2 \pi \times N_{m}}{60 \times \mathrm{xt}}=293.2 \mathrm{rad} / \mathrm{s}^{2}
$$

$\mathrm{T}_{3}=\left(\mathrm{J}+\mathrm{J}_{\mathrm{m}}\right) \times \omega_{\mathrm{b}}=1724.954 \mathrm{Nmm}$

Therefore, the required torques are:

Accelerating:

$$
T_{k 1}=T_{1}+T_{3}=18663 \mathrm{~N} \cdot \mathrm{mm}
$$

Constant acceleration increase:

$$
T_{t 1}=T_{1}=9423 \mathrm{~N}_{4} \cdot \mathrm{mm}_{\mathrm{mm}}
$$

Slow increase:

$$
\begin{aligned}
T_{g 1}=T_{1}-T_{3}=8183 \mathrm{~N} \cdot \mathrm{mm} \\
=16866.5 \mathrm{Nmm}
\end{aligned}
$$

Deceleration:

$$
T_{k 2}=T_{2}-T_{3}=78299 \mathrm{~N} \cdot \mathrm{mm}
$$

Constant deceleration decrease:

$$
T_{t 2}=T_{2}=\underline{9} 96999.2 \mathrm{Nmm}
$$

Slowly decrease:

$$
T_{g 2}=T_{2}+T_{3}=20309 \mathrm{~N} \cdot \mathrm{mm}
$$

So, $\mathrm{T}_{\max }=\mathrm{T}_{\mathrm{k} 1}$.

Table 6: Torque And Time Values

\begin{tabular}{|l|l|l|l|}
\hline \multicolumn{2}{|l|}{ torque } & time \\
\hline $\mathrm{T}_{\mathrm{k} 1}$ & $20316.3 \mathrm{Nmm}$ & $\mathrm{t} 1$ & $0.1 \mathrm{~s}$ \\
\hline $\mathrm{T}_{\mathrm{t} 1}$ & $18591.4 \mathrm{Nmm}$ & $\mathrm{t} 2$ & $0.4 \mathrm{~s}$ \\
\hline $\mathrm{T}_{\mathrm{g} 1}$ & $16866.5 \mathrm{Nmm}$ & $\mathrm{t} 3$ & $0.1 \mathrm{~s}$ \\
\hline $\mathrm{T}_{\mathrm{k} 2}$ & $16654.3 \mathrm{Nmm}$ & $\mathrm{t} 1$ & $0.1 \mathrm{~s}$ \\
\hline $\mathrm{T}_{\mathrm{t} 2}$ & $18379.2 \mathrm{Nmm}$ & $\mathrm{t} 2$ & $0.4 \mathrm{~s}$ \\
\hline $\mathrm{T}_{\mathrm{g} 2}$ & $20104.1 \mathrm{Nmm}$ & $\mathrm{t}_{3}$ & $0.1 \mathrm{~s}$ \\
\hline
\end{tabular}

$$
\begin{aligned}
T_{r m s} & =\sqrt{\frac{T_{k 1}^{2} \cdot t_{1}+T_{t 1}^{2} \cdot t_{2}+T_{g 1}^{2} \cdot t_{3}+T_{k 2}^{2} \cdot t_{1}+T_{t 2}^{2} \cdot t_{2}+T_{g 2}^{2} \cdot t_{3}}{t_{1}+t_{2}+t_{3}+t_{1}+t_{2}+t_{3}}} \\
& =9275 \mathrm{~N} \cdot \mathrm{mm}_{\mathrm{r}} \mathrm{r}_{\mathrm{rms}}=18512.41 \mathrm{Nmm}
\end{aligned}
$$

Therefore Sizing the Drive Motor is:

- rated torque of the motor must be above $\mathrm{T}_{\mathrm{rms}}$

- Maximum operating speed 1800rpm

- Motor rated speed 2000rpm 
International Journal of Science and Research (IJSR)

ISSN (Online): 2319-7064

Index Copernicus Value (2013): 6.14 | Impact Factor (2014): 5.611

\section{Modeling Using UG6.0}

After finishing the calculations, the parts of 3 dof parallel manipulator can be modeled by using UG 6.0.

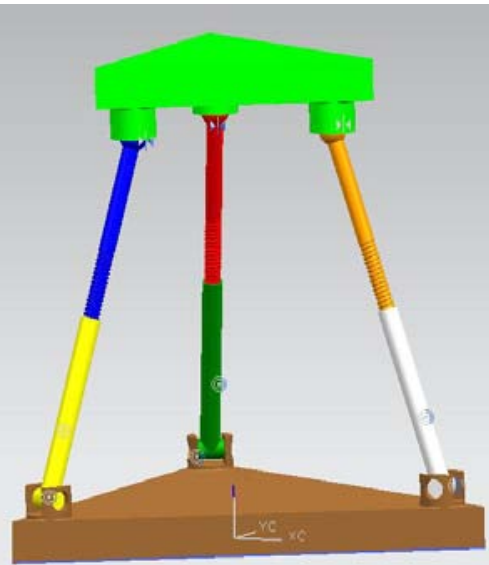

Figure 6: 3 DOF parallel manipulator in UG

\section{Simulation In ADAMS}

The manipulator is imported to ADAMS and constrains was applied to the model accordingly with the prismatic joint as the actuated joint as in the chart below. Also the friction force was applied to prismatic joint of each limb with gravitational force of $15680 \mathrm{~N}$ applied to the moving platform centre.also the maximmum stroke length is $100 \mathrm{~mm}$. For the model in question forces at each prismatic joint was analysed. Two different functions were used i.e. SINE FUNCTION. The result obtained by the two was compared at each stage of simulation.

Note: the model has three motions (Up and down ,Roll ,Pitch). Here we will using roll or pitch in simulation.

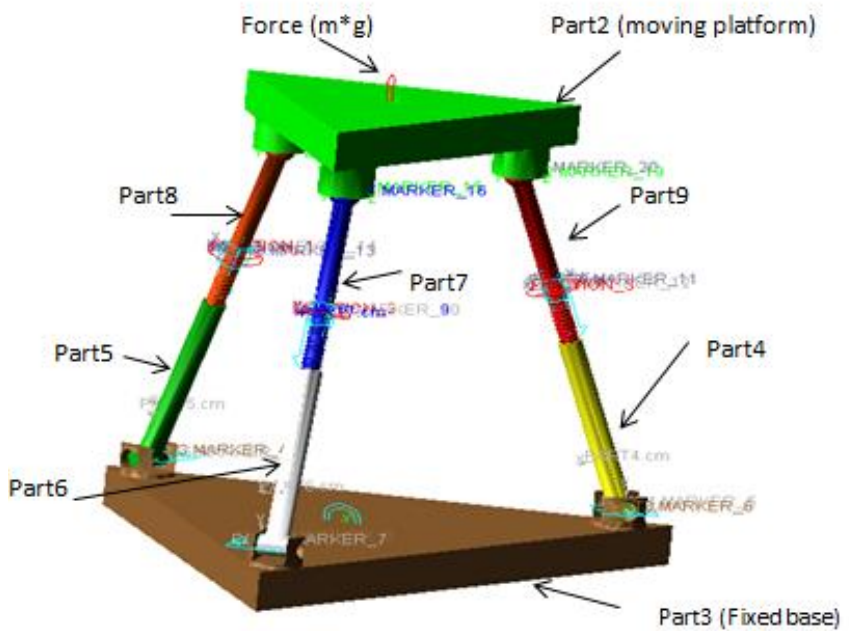

Table 7: the joints according to fig 5-1 in ADAMS

\begin{tabular}{|c|c|c|c|}
\hline $\begin{array}{l}\text { No of } \\
\text { joint }\end{array}$ & Name of joint & figure & place \\
\hline 1 & Fixed Joint & & on the part3 \\
\hline 2 & Revolute joint & & $\begin{array}{c}\text { Between part3 and } \\
\text { part5 }\end{array}$ \\
\hline 3 & Revolute joint & & $\begin{array}{c}\text { Between part3 and } \\
\text { part4 }\end{array}$ \\
\hline 4 & Revolute joint & & $\begin{array}{c}\text { Between part3 and } \\
\text { part6 }\end{array}$ \\
\hline 5 & $\begin{array}{c}\text { Translational } \\
\text { joint }\end{array}$ & & $\begin{array}{c}\text { Between part6 and } \\
\text { part7 }\end{array}$ \\
\hline 6 & $\begin{array}{c}\text { Translational } \\
\text { joint }\end{array}$ & & $\begin{array}{c}\text { Between part4 and } \\
\text { part9 }\end{array}$ \\
\hline 7 & $\begin{array}{c}\text { Translational } \\
\text { joint }\end{array}$ & & $\begin{array}{l}\text { Between part5 and } \\
\text { part8 }\end{array}$ \\
\hline 8 & $\begin{array}{l}\text { Spherical } \\
\text { joint }\end{array}$ & & $\begin{array}{c}\text { Between part2 and } \\
\text { part7 }\end{array}$ \\
\hline 9 & $\begin{array}{l}\text { Spherical } \\
\text { joint }\end{array}$ & & $\begin{array}{c}\text { Between part } 2 \text { and } \\
\text { part8 }\end{array}$ \\
\hline 10 & $\begin{array}{l}\text { Spherical } \\
\text { joint }\end{array}$ & & $\begin{array}{c}\text { Between part2 and } \\
\text { part9 }\end{array}$ \\
\hline
\end{tabular}

\subsection{Forces At Prismatic Joints}

8.1.1 Sine Function of $1406.536 \mathrm{~d} *(1-\sin ($ time $))$, $406.536 \mathrm{~d} *(1-\sin ($ time $))$, and $1406.536 \mathrm{~d} *(1+\sin ($ time $))$ were used at first, second and third limb to find the position of the moving prismatic joint parts, force at each prismatic joint and orientation of the moving platform.

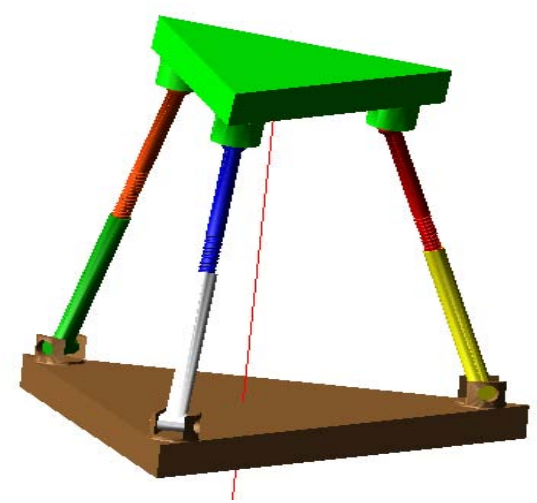

Figure 8: model during the simulation

Figure 7: model before the simulation 


\section{International Journal of Science and Research (IJSR) \\ ISSN (Online): 2319-7064}

Index Copernicus Value (2013): 6.14 | Impact Factor (2014): 5.611

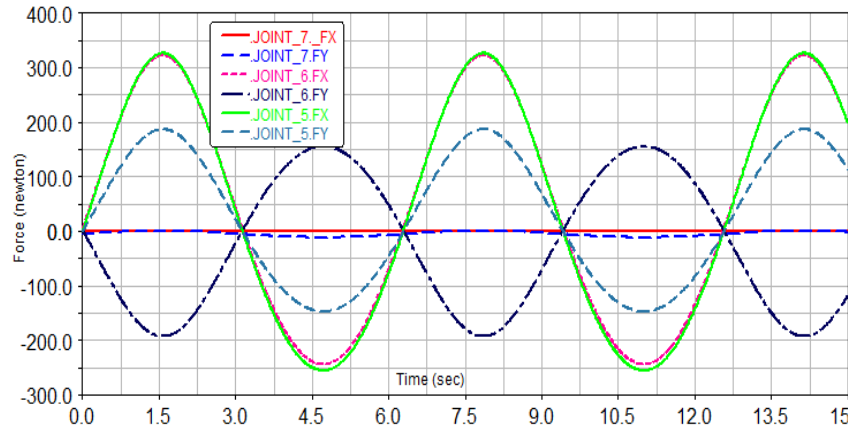

Graph 1 plots of forces at each limb for $(50 \mathrm{~mm})$

8.1.2 Sine Function of $2813.071 \mathrm{~d}^{*}(1-\sin ($ time $))$

2813.071d*(1-sin(time)), and 2813.071d*(1+sin(time)), were used at first, second and third limb to find the position of the moving prismatic joint parts, force at each prismatic joint and orientation of the moving platform.

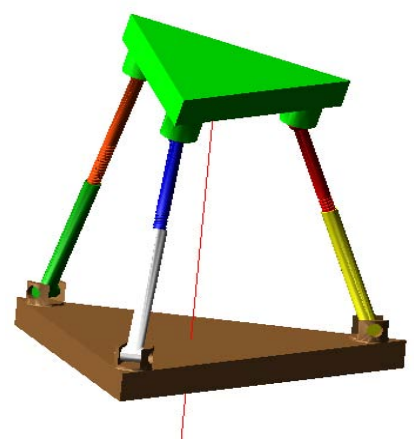

Figure 9: model during the simulation

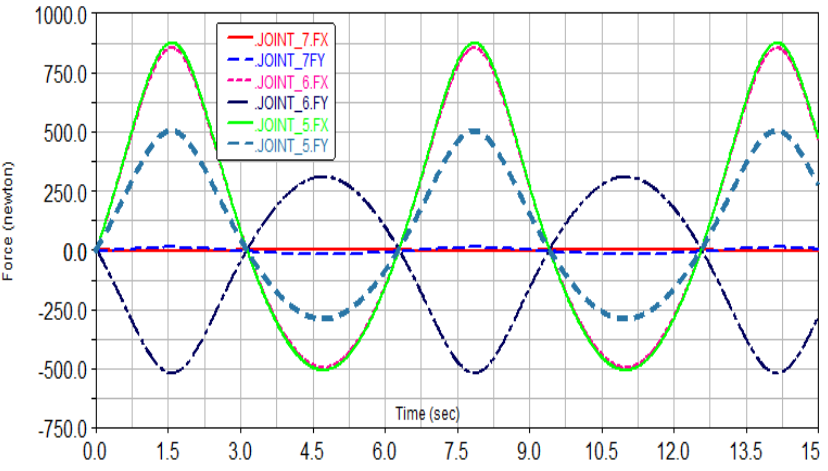

Graph 2 plots of forces at each limb for $(100 \mathrm{~mm})$

Table 8: Forces Results

\begin{tabular}{|c|c|c|c|}
\hline 2 & 1 & $\mathrm{~S} / \mathrm{N}$ & \\
\hline $\begin{array}{l}\text { 2813.071d } *(1 \sin (\text { time })) \\
2813.071 d^{*}(1-\sin (\text { time })) \\
2813.071 d^{*}(1+\sin (\text { time }))\end{array}$ & $\begin{array}{l}1406.536 d *(1-\sin (\text { time })) \\
1406.536 d *(1-\sin (\text { time })) \\
1406.536 d *(1+\sin (\text { time }))\end{array}$ & Functions & \\
\hline 875.52 & 326.46 & Fx Max $(\mathrm{N})$ & \multirow{4}{*}{$\underset{1}{\operatorname{Limb}}$} \\
\hline-506.75 & -255.1759 & Fx Min $(\mathrm{N})$ & \\
\hline 502.24 & 186.947 & Fy $\operatorname{Max}(\mathrm{N})$ & \\
\hline-291.8 & -147.15 & Fy Min $(\mathrm{N})$ & \\
\hline 853.73 & 322.82 & Fx Max $(\mathrm{N})$ & \multirow{4}{*}{$\underset{2}{\operatorname{Limb}}$} \\
\hline-494.1 & -243.876 & $F x \operatorname{Min}(\mathrm{N})$ & \\
\hline-518.77 & -192.74 & Fy Max (N) & \\
\hline 309.68 & 155.7 & Fy Min $(\mathrm{N})$ & \\
\hline-0.64 & -0.5 & Fx $\operatorname{Max}(\mathrm{N})$ & \multirow{4}{*}{ Limb3 } \\
\hline-0.282 & -0.35 & Fx Min $(\mathrm{N})$ & \\
\hline-16.74 & -11.089 & Fy Max $(\mathrm{N})$ & \\
\hline 12.32 & 1.435 & Fy $\operatorname{Min}(\mathrm{N})$ & \\
\hline
\end{tabular}

\section{Conclusion}

Design of structure of parallel robotic mechanisms is a key issue in robotic area. In this paper, the structural designs are carried out, such as the screw shaft and nut calculation, the load calculation, the motor specifications selection, according to the given paremeters. Then the model is established by using UG 6.0. From forces results in table 8 the forces (Fx,Fy) changed accorrding to the function (strok length) .

\section{Appreciation}

The work was supported by Scientific Research Development Fund of Tianjin University of Technology and Education (KJY14-02).

\section{References}

[1] L. W Tsai, Robot Analysis: The Mechanics Of Serial And Parallel Manipulators, Wiley, New York, 1999.

[2] Ginger Shifa, Review and Development of the flight simulator, electro-optical and Control, 1998 (3): 8-12 .

\section{Volume 4 Issue 12, December 2015}




\section{International Journal of Science and Research (IJSR) \\ ISSN (Online): 2319-7064}

Index Copernicus Value (2013): 6.14 | Impact Factor (2014): 5.611

[3] Lung- Wen Tsai, Robot Analysis: The Mechanics Of Serial And Parallel Manipulators, college park Maryland.

[4] Zafer Bingul and Oguzhan Karahan (2012). Dynamic Modeling and Simulation of Stewart Platform, Serial and Parallel Robot Manipulators - Kinematics, Dynamics, Control and Optimization, Dr. Serdar Kucuk (Ed.), ISBN: 978-953-51-0437-7,

[5] Ball Screw : General Catalog ,A Technical Descriptions of the Products.

[6] J.-P. MERLET ,Parallel Robots , Springer,P.O. Box 17, 3300 AA Dordrecht, The Netherlands.

Volume 4 Issue 12, December 2015 